\title{
Novel Insights Into the Early Stages of Ratoon Stunting Disease of Sugarcane Inferred from Transcript and Protein Analysis
}

\author{
Mariana Cicarelli Cia, Giselle de Carvalho, Ricardo Antunes Azevedo, Claudia Barros Monteiro-Vitorello, \\ Glaucia Mendes Souza, Milton Yutaka Nishiyama-Junior, Carolina Gimiliani Lembke, Raphael Severo da Cunha \\ Antunes de Faria, João Paulo Rodrigues Marques, Maeli Melotto, and Luis Eduardo Aranha Camargo†
}

First, second, third, fourth, eighth, ninth, and eleventh authors: Escola Superior de Agricultura Luiz de Queiroz, Universidade de São Paulo, Av. Pádua Dias, 11, 13418-900, Piracicaba, SP, Brazil; fifth and seventh authors: Instituto de Química, Universidade de São Paulo, Av. Prof. Lineu Prestes, 748, 05508-900, São Paulo, SP, Brazil; sixth author: Instituto Butantan, Laboratório Especial de Toxinologia Aplicada, Av. Vital Brasil, 1500, 05503-900, São Paulo, SP, Brazil; and tenth author: Department of Plant Sciences, University of California, Davis 95616. Accepted for publication 27 June 2018.

\begin{abstract}
Despite of the importance of ratoon stunting disease, little is known on the responses of sugarcane to its causal agent, the vascular bacterial endophyte Leifsonia xyli subsp. xyli. The transcriptome and proteome of young plants of a susceptible cultivar with no symptoms of stunting but with relative low and high bacterial titers were compared at 30 and 60 days after inoculation. Increased bacterial titers were associated with alterations in the expression of 267 cDNAs and in the abundance of 150 proteins involved in plant growth,

alterations are predicted to benefit the pathogen, such as the up-regulation of genes involved in the synthesis of methionine. Also, genes and proteins of the cell division cycle were all down-regulated in plants with higher titers at both times. It is hypothesized that the negative effects on cell division related to increased bacterial titers is cumulative over time and its modulation by other host and environmental factors results in the stunting symptom.
\end{abstract} hormone metabolism, signal transduction and defense responses. Some
Additional keywords: microarray, plant-pathogen interaction.
Ratoon stunting disease (RSD) of sugarcane occurs worldwide (Young 2016) and because of stunting it can cause a substantial impact on biomass production. Annual losses were estimated at US\$ 11 million in Australia (Fegan et al. 1998) and US\$ 36 million in Florida (Dean and Davis 1990). In Brazil, a recent study reported an annual loss of US\$ 1 million considering only the incidence of RSD in the most planted variety grown in $29 \%$ of the cultivated area (Urashima et al. 2017). RSD, caused by the gram-positive Actinobacteria Leifsonia xyli subsp. xyli, is regarded as one of the least tractable diseases of sugarcane because its external symptoms, characterized by reduction in height and in stalk diameter, can be easily mistaken by the effects of other factors that affect plant growth.

The main control method of RSD relies on using healthy cuttings (setts) taken from in vitro cultured or heat-treated canes raised in nurseries as planting material. Immersion of setts in hot water (50 to $52^{\circ} \mathrm{C}$ ) for 30 to $120 \mathrm{~min}$ is the most used heat treatment but its efficiency in eradicating the bacterium is variable (Carvalho et al. 2016; Damann and Benda 1983), which contributes to the high incidence of $L$. xyli subsp. xyli-infected plants reported in commercial fields (Li et al. 2014; Ponte et al. 2010; Rago et al. 2004; Urashima and Marchetti 2013). Since sugarcane varieties

${ }^{\dagger}$ Corresponding author: L. E. A. Camargo; E-mail: leacamar@usp.br

Funding: This study is part of the Ph.D. theses of M. C. Cia and G. Carvalho supported by Fundação de Amparo à Pesquisa do Estado de São Paulo grants 2008/ 56260-2 and 2015/18681-0. J. P. R. Marques was supported by a scholarship from Fundação de Amparo à Pesquisa do Estado de São Paulo (grant 2012/25315-1). Funding was also provided by Conselho Nacional de Desenvolvimento Científico e Tecnológico grant 303613/2013-0.

First and second authors contributed equally to this work.

*The $\boldsymbol{e}$-Xtra logo stands for "electronic extra" and indicates that one supplementary figure and three supplementary tables are published online.

(C) 2018 The American Phytopathological Society differ in their resistance to $L$. xyli subsp. xyli multiplication (Comstock et al. 1996; Davis et al. 1988), breeding and selection for $L$. xyli subsp. xyli-restrictive varieties represents a promising control strategy. However, although the disease was first described more than 70 years ago, there is little information on the molecular and physiological mechanisms of sugarcane involved in the interaction with L. xyli subsp. xyli.

Stunting is attributed to the plugging of the xylem vessels and resulting water stress by the association of bacterial cells and a matrix of uncertain origin and composition observed in basal internodes of mature stalks (Kao and Damann 1978) and resistance has been associated to the anatomy of the vessels which are more branched in resistant genotypes thus presumably restricting colonization (Teakle et al. 1978). At the physiological level, aside from impairing the activity of acid invertase in buds (Madan et al. 1986), modulating the activity of antioxidative enzymes and negatively interfering in photosynthetic parameters (Zhang et al. 2016a), it has also been reported that infection with $L$. xyli subsp. xyli induces changes in the production of auxin (IAA), gibberellic acid (GA), and abscisic acid (ABA) (Zhang et al. 2016b). At the gene expression level, a study based on hybridizations of cDNA arrays containing 3,575 expressed sequenced tags (EST) identified 49 genes mostly related to signal transduction with altered expression in response to inoculation with L. xyli subsp. xyli (Ferro et al. 2007). Due to the poor understanding of RSD and to the lack of cost-effective and high-throughput screening methods to select resistant genotypes at the seedling stage, selection for resistance to this disease has not been the focus of breeding programs (DalBianco et al. 2012). Thus, knowledge on the mechanisms involved in the early stages of the disease may reveal candidate genes that could be used as markers to identify resistant genotypes.

L. $x y l i$ subsp. $x y l i$ is a peculiar plant pathogen in many aspects. So far, its only described natural host is sugarcane (Mills et al. 2001; Zavaglia et al. 2016), where it systemically colonizes the xylem vessels, the mesophyll, and the bundle sheath cells (Bailey 1977; 
Quecine et al. 2015). Its genome has an unusually high number of pseudogenes, indicating that it has undergone a process of genome decay that could account both for this restricted host range and for its slow and fastidious growing habit (Monteiro-Vitorello et al. 2004). Also, there is a remarkable low level of genetic variability among isolates, suggesting that it comprises a clonal population (Young et al. 2006; Zhang et al. 2016b). A recent review on the origin of RSD proposes that the progenitor species of modern sugarcane cultivars, Saccharum officinarum is not the natural host of $L$. xyli subsp. xyli but rather that the bacterium was acquired as an endophyte from $S$. spontaneum after artificial interspecific hybridization carried out at the beginning of the last century (Young 2016). As the damage caused by L. xyli subsp. xyli is directly correlated to its concentration in plant tissues (Bailey 1977; Davis et al. 1988; McFarlane 2002; Zekarias et al. 2012) and it can be detected in plants with no stunting or internal symptoms, this bacterium can be considered an endophyte whose pathogenicity depends on biotic and abiotic factors that control its multiplication in the host.

The objectives of this study were to compare changes in the transcriptome and in the proteome of a susceptible sugarcane variety in response to variations in the concentration of the pathogen within its tissues at the beginning of disease development before the appearance of the stunting symptom. For this, infected plants with low bacterial titers were either mock-inoculated or inoculated with L. $x y l i$ subsp. xyli in this case to create plants with increased bacterial titers, and changes in the abundance of approximately 2,500 proteins and in the expression of 14,522 sugarcane expressed sequenced tags (SAS) were compared at two times after inoculation.

\section{MATERIALS AND METHODS}

Plant material and inoculation. Three-bud setts of the susceptible variety SP80-3280 were harvested from L. xyli subsp. $x y l i$-infected first ratoon plants which are kept in a greenhouse as a source of inoculum for experimental purposes and thermally treated by water immersion at $50.5^{\circ} \mathrm{C}$ for $2 \mathrm{~h}$ to reduce the population levels of $L$. xyli subsp. xyli (Carvalho et al. 2016). The material was cut into one-bud setts using a disinfected cane knife, immersed in a fungicide solution ( $90 \mathrm{~g}$ of $70 \%$ thiophanate-methyl liter ${ }^{-1}$ of water) and planted in 0.5-liter pots containing Basaplant substrate (Base). Thirty days after planting, plants were transferred to 22.5-liter pots (3 plants/pot) containing a 2:1 mixture of steam-sterilized topsoil and substrate supplemented with $2 \mathrm{~g} \mathrm{liter}^{-1}$ of 15-8-12 Basacote (3M) slow release fertilizer and were inoculated 7 days after transplanting by cutting off the shoots $2 \mathrm{~cm}$ above the soil with sterile scalpel blades, perforating the remaining stub with sterile needles (three perforations/stub), and by placing $50 \mu \mathrm{l}$ of a liquid culture $\left(\mathrm{OD}_{600}=0.8\right)$ of $L$. xyli subsp. xyli strain CTCB07 grown in M-SC medium (Monteiro-Vitorello et al. 2004; Teakle and Ryan 1992) on the surface of the stub. The experiment consisted of four treatments: two inoculation conditions (inoculated with L. xyli subsp. xyli or mock-inoculated with sterile culture medium; LxxI or MI treatments, respectively) $\times$ two evaluation times ( 30 and 60 days after inoculation [DAI]). The evaluation times were chosen based on previous data which indicated that 30 DAI was the minimum time required to detect increases in bacterial titers after inoculation and at 60 DAI these increases were more pronounced (G. de Carvalho, unpublished data). Each treatment was represented by three replicates arranged in a randomized block design and each replicate was composed of a pot with three plants. For $L$. xyli subsp. xyli quantification and RNA and protein extraction, $1 \mathrm{~g}$ of leaf whorl tissue including the shoot apex was collected from each plant of a replicate and pooled. $L$. $x y l i$ subsp. $x y l i$ was quantified by real-time PCR (Carvalho et al. 2016).

RNA extraction, microarray hybridization, and data analysis. Total RNA was extracted from $100 \mathrm{mg}$ of plant tissue with
Trizol (Thermo Fisher Scientific, Waltham, MA), treated with DNAse I Amplification Grade enzyme (Thermo Fisher Scientific), and purified with RNeasy Mini Kit (Qiagen, Hilden, Germany). The concentration of RNA was determined in a NanoDrop (Thermo Scientific, Waltham, MA) and its quality was evaluated on $1 \%$ agarose/formaldehyde gel. Two of the biological replicates were used for microarray hybridizations. An aliquot of the RNA was used as template in a PCR reaction to assess the possibility of DNA contamination. Hybridizations were performed on the customized sugarcane CaneRegNet 4x44K chip (Agilent Technologies, Santa Clara, CA) consisting of 43,802 probes corresponding to 14,522 sugarcane assemble sequences (SAS) released by the SUCEST (Sugarcane EST) project (Lembke et al. 2012; Vettore et al. 2003). Sample preparation, hybridizations and data analysis were performed according to Lembke et al. (2012). Comparisons were made between LxxI and MI plants within each time after inoculation. Dye swaps were used for each time point analyzed. The normalization was composed of two steps using a nonlinear LOWESS normalization and a modified HTself method (Lembke et al. 2012; Vêncio and Koide 2005). A gene was considered as differentially expressed if $95 \%$ of confidence was obtained using the modified HTself method. The data are available in the GEO (Gene Expression Omnibus) of the National Center for Biotechnology Information (NCBI; https://www.ncbi.nlm.nih.gov/ geo/) under the accession number GSE87826.

Validation of differentially expressed genes by real-time quantitative PCR (qPCR). Differentially expressed genes were selected from each time point for validation by qPCR. Primers for these genes were designed using the software Primer3Plus (Untergasser et al. 2007). The specificity of the primers was checked in silico against the SUCEST database (www.sucest-fun. org) using the BlastN tool and by checking for the presence of a unique peak in the melting curve of the qPCR. Primer efficiency was evaluated using the software LinReg PCR (Ramakers et al. 2003). cDNA was synthesized using the SuperScript III First-Strand Synthesis Super Mix (Thermo Fisher Scientific). PCR amplifications were done using Platinum Sybr Green qPCR supermix UDG kit (Thermo Fisher Scientific). The analysis of differentially expressed genes was performed with the REST software (Pfaffl et al. 2002). All qPCR reactions were run in duplicates. The polyubiquitin and 14-3-3 (accession IDs SCCCST2001G02.g and SCCCLR1048F12.g) genes were used as normalizers (Papini-Terzi et al. 2005). The three biological replicates were used for validation. The R software was used to calculate the Pearson's correlation coefficient between the microarray and the qPCR data.

Extraction and precipitation of leaf proteins. Proteins were extracted from $0.5 \mathrm{~g}$ of plant tissue macerated in $10 \mathrm{ml}$ of extraction buffer $(10 \%, \mathrm{wt} / \mathrm{vol}$, trichloroacetic acid and $0.7 \%$, vol $/ \mathrm{vol}$, 2-mercaptoethanol in acetone) and precipitated for $2 \mathrm{~h}$ at $-20^{\circ} \mathrm{C}$. The tubes were centrifuged for $15 \mathrm{~min}$ at $12,000 \mathrm{rpm}$ and $-20^{\circ} \mathrm{C}$, the supernatant was discarded, and the pellet was washed twice with $0.7 \%$ 2-mercaptoethanol in acetone, dried at $4^{\circ} \mathrm{C}$, and resuspended in a solubilizing buffer ( $33 \mathrm{mg}$ of pellet/1 ml of buffer) containing $7 \mathrm{M}$ urea, $2 \mathrm{M}$ thiourea, 4\% CHAPS, 2\% Pharmalyte (immobilized pH gradient buffer [IPG]), and $0.3 \%$ of DTT (Amalraj et al. 2010). An aliquot was used for total protein quantification by the Bradford assay using bovine serum albumin as a standard. The proteins were precipitated in a methanol solution with $0.1 \mathrm{M}$ ammonium acetate at $-20^{\circ} \mathrm{C}$ for $12 \mathrm{~h}$. A ratio of $1,200 \mu \mathrm{l}$ of precipitant solution to $300 \mu \mathrm{l}$ of protein sample was used. The tubes were centrifuged at 12,000 rpm for $30 \mathrm{~min}$ at $4^{\circ} \mathrm{C}$ and the supernatant was discarded. Then, $80 \%$ methanol was added to the pellet and these were kept at $-20^{\circ} \mathrm{C}$ for 1 $\mathrm{h}$. The tubes were centrifuged at $12,000 \mathrm{rpm}$ for $30 \mathrm{~min}$ at $4^{\circ} \mathrm{C}$ and the supernatant was discarded. Acetone $(80 \%)$ was added to the pellet and this was kept at $-20^{\circ} \mathrm{C}$ for $1 \mathrm{~h}$ and centrifuged again at $12,000 \mathrm{rpm}$ for $30 \mathrm{~min}$ at $4^{\circ} \mathrm{C}$. The supernatant was discarded, and the final pellet was dried at $4^{\circ} \mathrm{C}$ in a desiccator for 1 day and stored in $100 \mu \mathrm{l}$ of ethanol. 
Two-dimensional fluorescence difference gel electrophoresis (2D-DIGE). Analyses were performed at Applied Biomics (Hayward, CA) according to standardized procedures. Briefly, proteins were solubilized in buffer $(30 \mathrm{mM}$ Tris-HCl, $\mathrm{pH} 8.8$, containing $7 \mathrm{M}$ urea, $2 \mathrm{M}$ thiourea, and 4\% CHAPS) for analysis in 2D gels, and quantified with the Bio-Rad Protein Assay kit (BioRad, Hercules, CA). Proteins of the MI treatments were labeled with Cy3-red and those from the LxxI treatment were labeled with Cy5-blue. Proteins of an internal standard (IS) comprising an equimolar mixture of all samples were labeled with Cy2-yellow. Labeled samples were subjected to isoelectric focusing performed in IPG strips at pH 3 to 10 (GE Healthcare, Chalfont St. Giles, U.K.) and were separated by size in SDS-PAGE. Twenty-five micrograms of protein per sample/run was used.

Gel images were generated in a Typhoon Trio imager (GE Healthcare) and analyzed using the ImageQuant software (v.6.0, GE Healthcare). The standardization and statistical analysis of protein volumes were carried out using the biological variation analysis (BVA) module of the DeCyder software (v.6.5, GE Healthcare). Comparisons of normalized protein abundances were made within each time between the LxxI30 versus MI30 and the LxxI60 versus MI60 treatments as in the transcriptome experiment as well as between times for L. xyli subsp. xyli-inoculated (LxxI60 versus LxxI30) and mock-inoculated (MI60 versus MI30) treatments using Student's $t$ test. Proteins with significant variations in abundance $(P<0.05)$ and mean fold changes $(r)$ lower than -1.3 or greater than 1.3 were considered as differentially accumulated and chosen for MS analysis.

Protein sequencing. Selected proteins were excised from the gel using an Ettan Spot Picker device (GE Healthcare), dried, hydrated, and digested with trypsin in digestion buffer (Trypsin Gold, Promega, Madison, WI) at $37^{\circ} \mathrm{C}$. Peptides were extracted from the gel in TFA buffer under agitation, desalinated using C-18 Zip-Tips (Millipore, Billerica, MA) columns, mixed with CHCA matrix (alpha-cyano-4-hydroxycinnamic acid), and analyzed by MALDI-TOF-MS and TOF/TOF tandem MS/MS in an AB SCIEX TOF/TOFTM 5800 system (AB SCIEX, Framingham, MA). Approximately 10 to 20 of the most abundant peptides in each sample (excluding autolytic trypsin peptides and other known background ions) were subjected to fragmentation and tandem mass spectrometry analysis.

Peptide spectra were used in searches against the NCBI nonredundant protein database using the GPS Explorer and MASCOT software (www.matrixscience.com) to identify proteins with similar spectra. Searches were performed with no constraints to protein molecular weight or isoelectric point, with variable carbamidomethylation of cysteine and oxidation of methionine residues and allowing one missed cleavage in the parameters. Only hits with confidence intervals $>95 \%$ for protein or total ion scores were considered significant and among these the hit with the highest score was reported.

Bioinformatic analyses and data mining. Differentially expressed genes and proteins were assigned to functional categories based on the classification of the SUCEST database (Vettore et al. 2003).

\section{RESULTS}

Quantification of bacterial titers and plant growth. L. xyli subsp. xyli titers differed $(P<0.05)$ between MI and LxxI plants at both times, indicating that the inoculation method was successful in establishing treatments with different bacterial densities (Fig. 1). Moreover, the endophytic levels of $L$. xyli subsp. $x y l i$ increased fivefold in the mock-inoculated plants in the lapse of 30 days ( 7 and 34 L. xyli subsp. xyli cells/100 ng of plant DNA at 30 and 60 DAI, respectively; $P<0.05$ ), whereas in the inoculated plants, bacterial titers increased 10 -fold (27 and 263 L. xyli subsp. xyli cells/100 ng of plant DNA at 30 and 60 DAI, respectively; $P<$

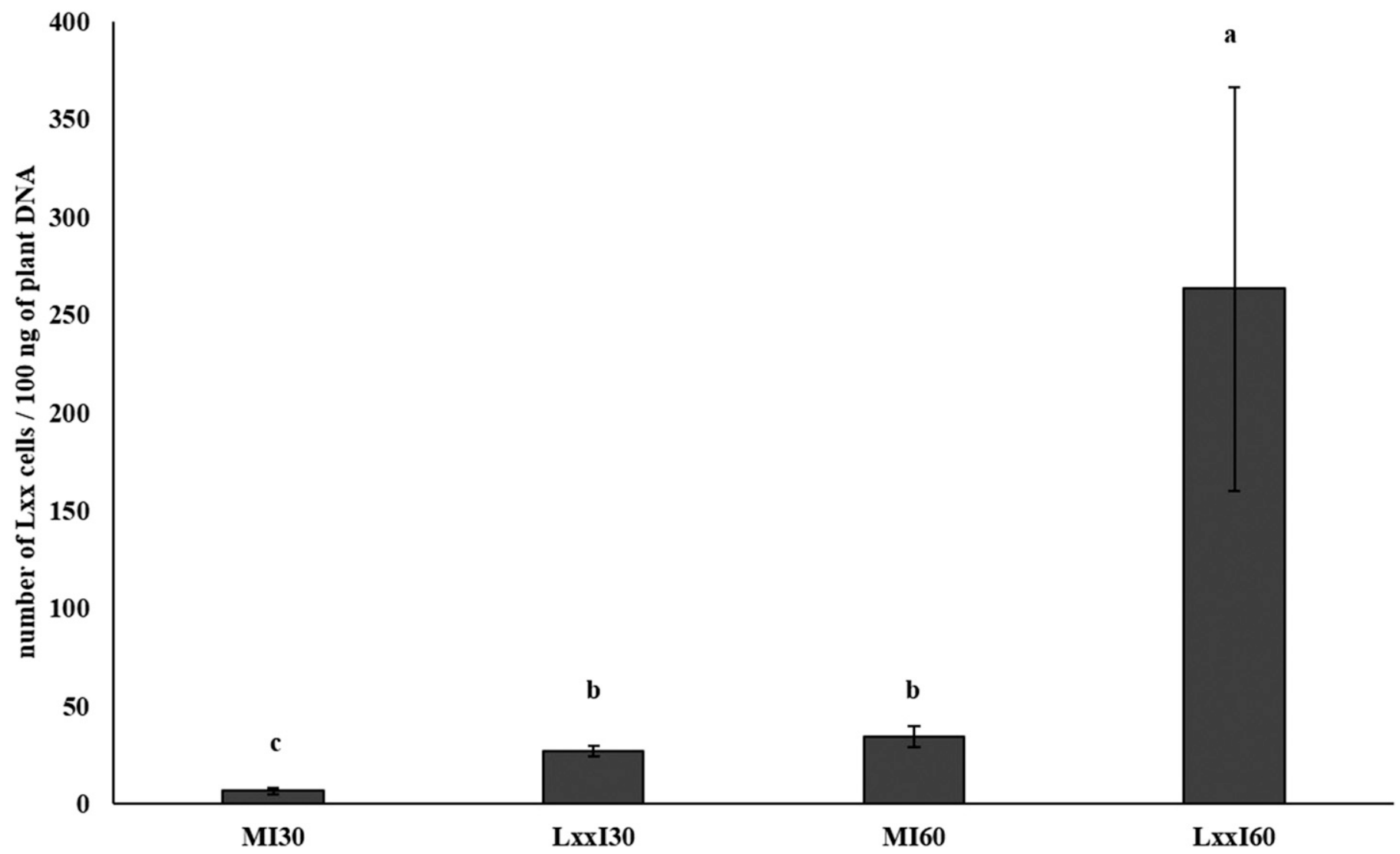

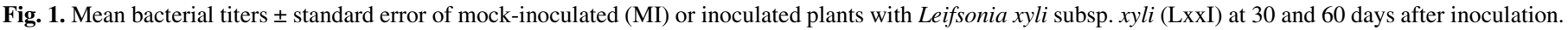
Letters indicate different means based on paired Student's $t$ test $(P<0.05)$. 
0.05). These titers are in the same order of magnitude as those reported for 8-month-old first-ratoon plants of the same variety (Carvalho et al. 2016). Notwithstanding the contrasting bacterial titers, LxxI and MI plants presented no visual differences in growth at both times. Also, no symptoms of water stress such as leaf rolling or senescence were observed in any treatment. The mean temperature and relative air humidity registered during the experiment was $25.5^{\circ} \mathrm{C}$ and $58 \%$, respectively.

Microarray. A total of 267 differentially expressed genes $(P<$ $0.05)$ were identified between the LxxI and the MI treatments (Supplementary Table S1). There were noticeable differences between the two times of analysis since only 14 genes (5\% of total) were differentially expressed at both times (Fig. 2). Most genes exclusively detected at 30 DAI were down-regulated (82 downregulated and 22 up-regulated), whereas most at 60 DAI were upregulated (110 up-regulated and 39 down-regulated) (Fig. 2). Moreover, differences were also found related to gene functional categories, as genes encoding proteins related to cytoskeleton functions were down-regulated only at 30 DAI whereas most of those related to hormone metabolism (ethylene, abscisic acid and IAA), were up-regulated only at $60 \mathrm{DAI}$ except for a lipoxygenase that also was up-regulated at $30 \mathrm{DAI}$. Another interesting difference relates to the regulation of genes involved in signal transduction, the majority of which were down-regulated at 30 DAI but up-regulated at 60 DAI. Notwithstanding these differences, a strikingly similar response was found between 30 and 60 DAI regarding the expression of genes related to the control of the cell division cycle, the largest represented category, where most were down-regulated (Fig. 3).

Validation of microarray data by real-time PCR quantification of gene expression (qPCR). Twenty-nine differentially expressed genes were chosen for validation (Supplementary Table S2), being 13 exclusives of each DAI and three common to both times. In all cases there was an agreement between the qPCR and the microarray results (Fig. 4). The Pearson's correlation coefficient between the microarray and the qPCR data were 0.82 , indicating a good correlation.

2D-DIGE. 2D-DIGE protein analysis provided a satisfactory resolution of approximately 2,500 proteins (Supplementary Fig.
S1). After image processing and statistical calculations based on standardized volumes of each protein spot, 155 proteins were detected with significant changes in abundance for the comparisons studied $(P<0.05)$. Abundance ratios ranged from -4.88 to +2.56 .

Variation in protein abundance as a function of variation in bacterial titers and of variation in bacterial titers and time. The effect of different bacterial titers on the abundance of proteins was studied by comparing LxxI and MI plants at each DAI (LxxI 30 versus MI30 and LxxI60 versus MI60). A second type of comparison was made between DAIs for the LxxI and MI (LxxI60 versus LxxI30 and MI60 versus MI30) to identify variations related both to differences in bacterial titers and to time. A total of 150 proteins from diverse functional classes were identified in these comparisons (Supplementary Table S3), being 7 in the first, 148 in the second, and 5 in both. In the first type of comparison, three were exclusive of each DAI and one (calreticulin 2) common to both (Fig. 2 ), whereas in the second type, 13 were identified exclusively in the mock-inoculated contrast (MI60 versus MI30), 66 were identified exclusively in the inoculated (LxxI60 versus LxxI30), and 69 were identified in both contrasts (Fig. 2). Among the 13 proteins of the (MI60 versus MI30) contrast, the largest number (5) belong to the defense class. In the (LxxI60 versus LxxI30) contrast, the carbohydrate metabolism class was the more numerous (25 proteins), followed by protein metabolism (15), and transcription regulation (6). Other classes with lower number of proteins were also detected, including the cell division cycle class. Proteins common to the MI60 versus MI30 and LxxI60 versus LxxI30 contrasts were grouped into various classes.

\section{DISCUSSION}

Increased bacterial titers induce discrete changes in gene expression and protein accumulation. Of the 14,522 SAS analyzed, significant changes were found in the expression levels of a small proportion of genes (1.9\%) in response to increased bacterial titers considering the two times of analysis. This agrees with a previous study which analyzed the expression of 3,575 ESTs also by hybridization of a cDNA array and found only 49 genes
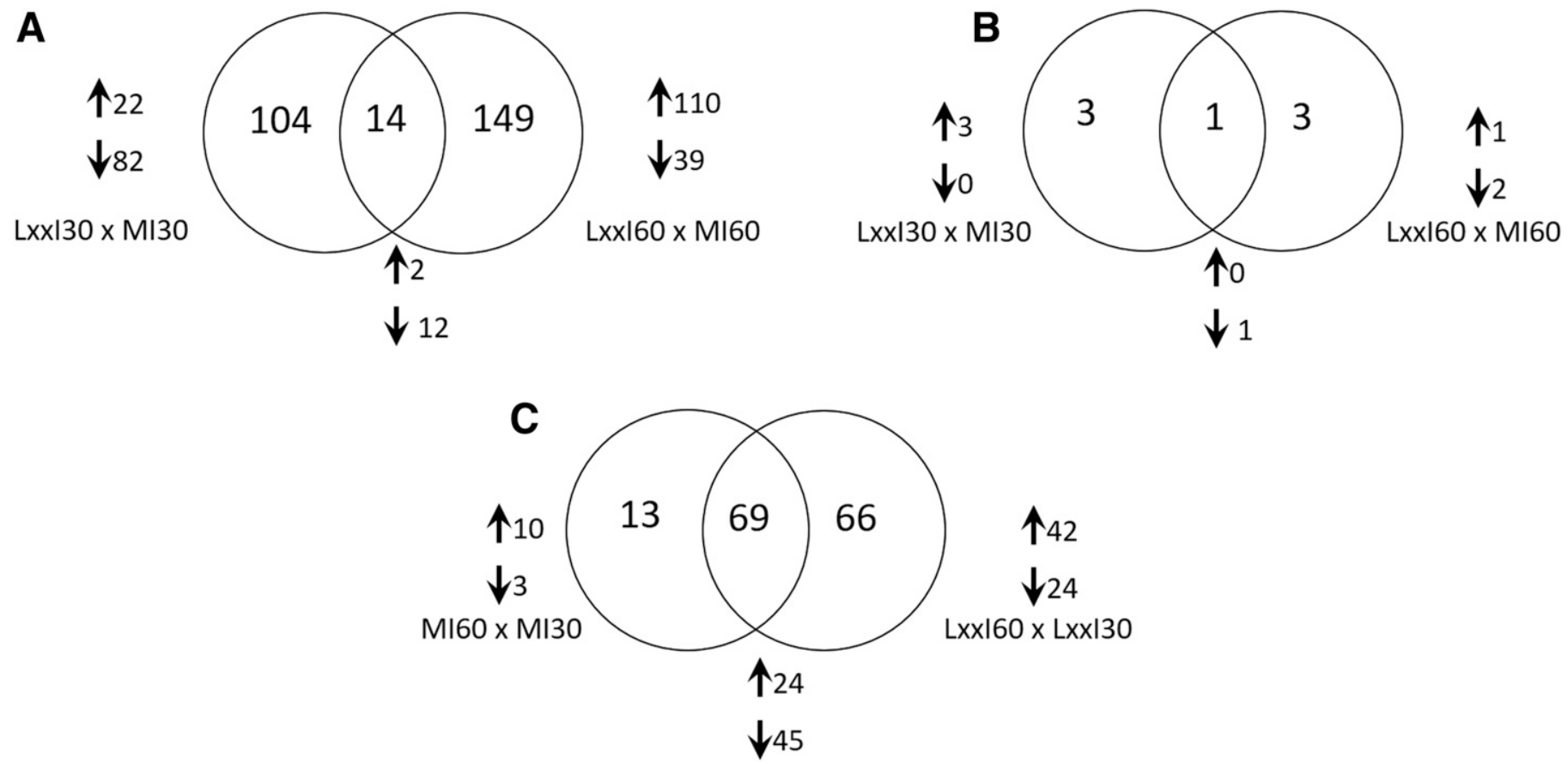

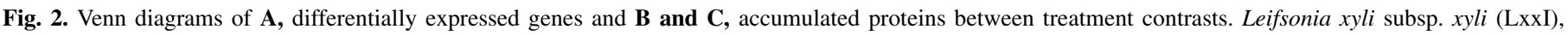

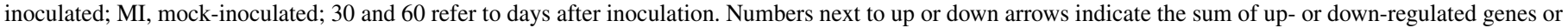
proteins in each contrast. 
(1.4\%) with altered expression in response to inoculation with L. xyli subsp. xyli (Ferro et al. 2007). This sharply contrasts with other pathosystems where intense transcriptional reprogramming is commonly reported most likely because our results reflect responses to quantitative changes in population densities of a slow-growing endophytic pathogen rather than to infection by biotrophic and necrotrophic pathogens which result in clearly defined symptoms within a short period. Also, the proportion of genes with altered expression could relate to the bacterial levels in the plant tissue and to the fact that we analyzed leaf whorl and shoot apex rather than xylem tissue where the bacterium grows. The number of differentially expressed genes was $43 \%$ higher at $60 \mathrm{DAI}$ than at $30 \mathrm{DAI}$, suggesting an increased transcriptional response of sugarcane to increased bacterial titers. Moreover, the small overlap between the sets of genes detected at these times suggests that the responses were not only quantitative but also qualitative in nature. Changes at the protein level, however, did not follow the changes in gene expression, since few differentially accumulated proteins were found between treatments at 30 and 60 DAI. This could be due not only to the general poor agreement between transcriptomic and proteomic studies caused by biological and methodological factors (Maier et al. 2009), but also possibly reflects the slower responses of the proteome to this type of vascular pathogen.

Plants with increased levels of $L$. xyli subsp. xyli present down-regulation of genes involved in the cell division cycle. Inoculation with $L$. xyli subsp. xyli resulted in the down-regulation of genes involved in the cell division cycle at both DAI. Among these are classical genes regulating the cell cycle progression and cell division, such as cyclin A (CycA), which is considered to be involved in the control of the S-M transition, cyclin B (CycB) and a cyclin dependent protein kinase $(\mathrm{CDKB} 1 ; 1)$ involved in the $\mathrm{G} 2-\mathrm{M}$ transition (Inzé and De Veylder 2006), and a gene coding for a syntaxin similar to the KNOLLE protein of Arabidopsis required for cytokinesis (Lauber et al. 1997). In addition, various genes coding for proteins required for successful chromosome replication and transmission (mini-chromosome maintenance proteins 2 to 7; origin recognition complex subunit 6; mitotic spindle checkpoint proteins MAD2 and MAD3; chromosomal structural maintenance proteins; microtubule associated proteins, condensins, kinesins, and chromatin assembly factor) were down-regulated. These results agree with the observed down-regulation of genes involved in DNA metabolism as the down-regulation of the cell division cycle is expected to be accompanied by a down-regulation in DNA replication and processing as well. Moreover, the repression of all genes of the cytoskeleton functional category at 30 DAI may also be related, since these comprise mostly kinesins, a protein family that includes members essential for cell growth and division by mediating the reorganization of the microtubules in anticipation of the mitotic division ( $\mathrm{Li}$ et al. 2012) and a gene encoding for a microtubule binding protein similar to TANGLED-1 of maize involved in the orientation of cytokinesis (Smith et al. 2001).

An interesting finding relates to a gene (SCCCLB1003E01.g) similar to one coding for a $14 \mathrm{kDa}$ proline-rich DC 2.15 protein of carrot that at 60 DAI was the most down-regulated gene of this study besides being down-regulated at $30 \mathrm{DAI}$ as well. In carrot as in other plant species, this gene occurs in small gene families and although not a classical gene of the cell cycle, it was tentatively considered as such because transcripts of similar genes from maize and bean

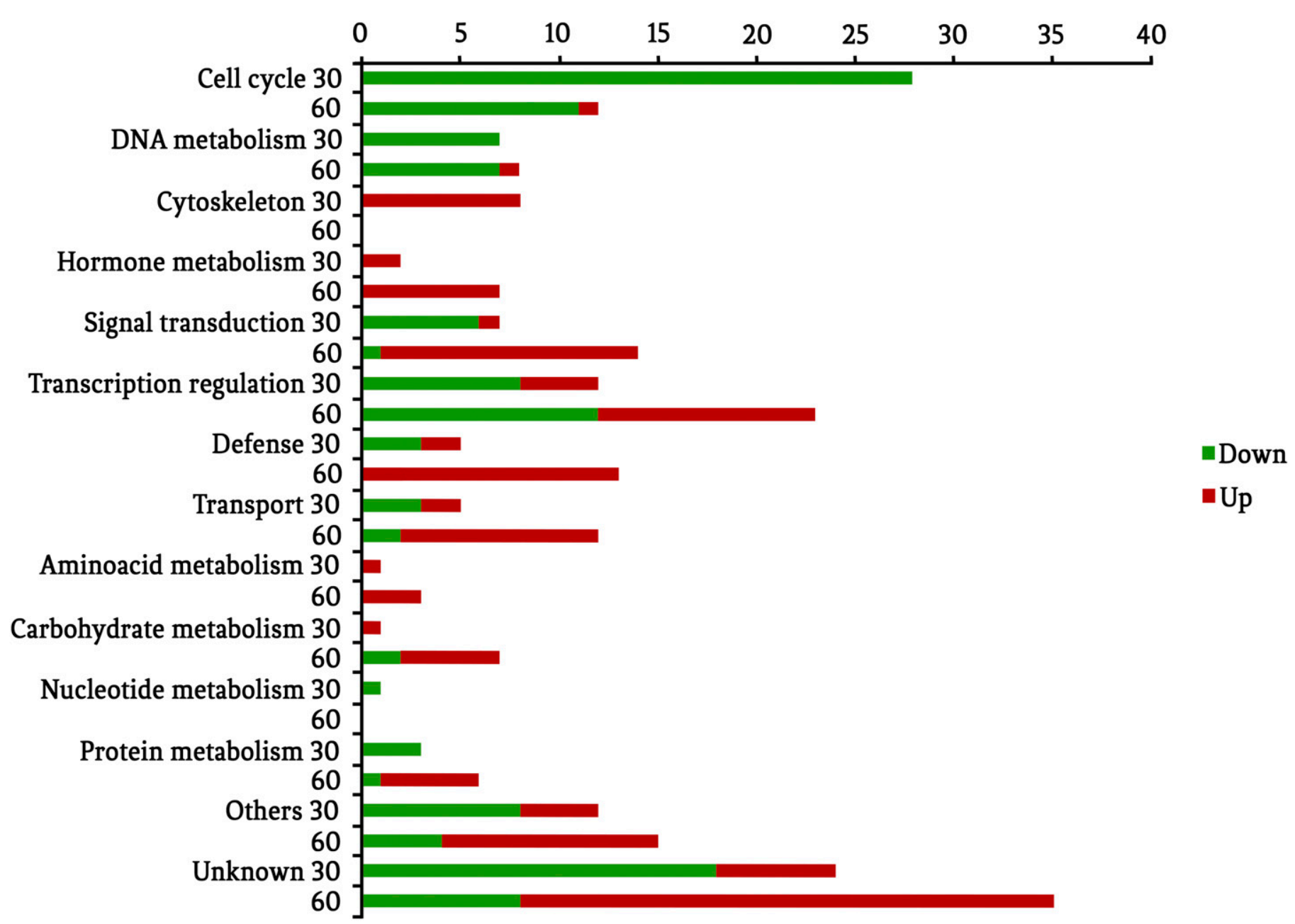

Fig. 3. Numbers of up- or down-regulated genes at 30 and 60 days after inoculation with Leifsonia xyli subsp. xyli based on the SUCEST functional categorization. 

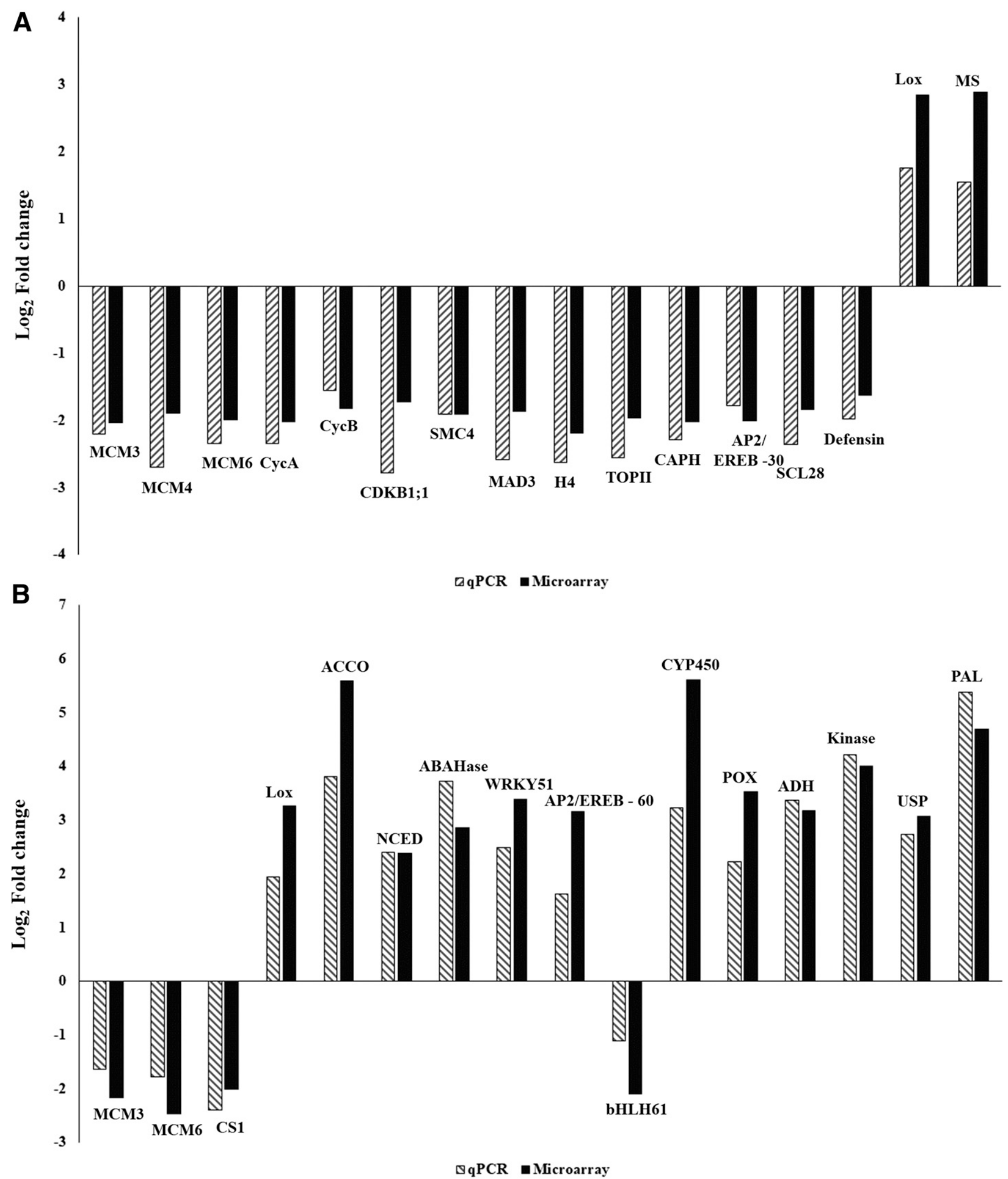

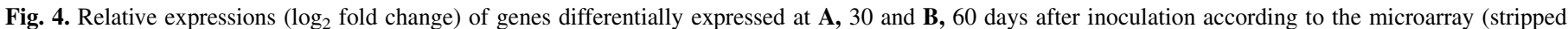

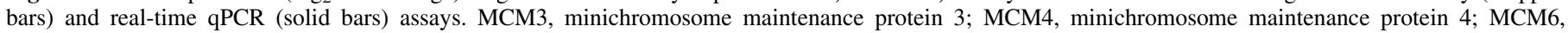

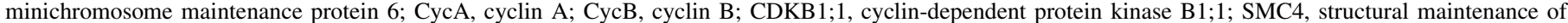

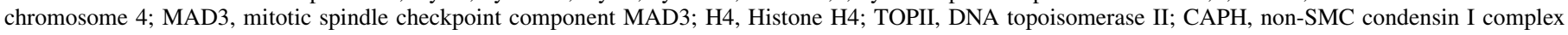

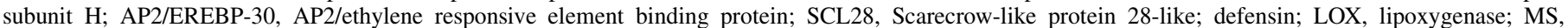

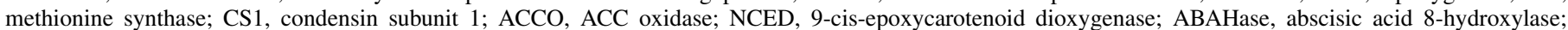

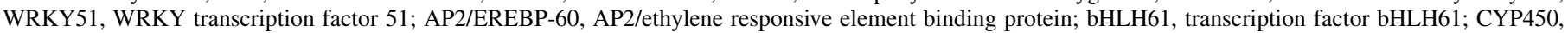

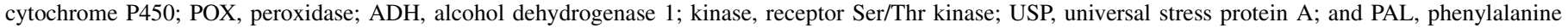
ammonia-lyase. 
specifically accumulate in the cortical region of the root meristem where cell division occurs (Choi et al. 1996; John et al. 1992). In addition, suppression of its expression in carrot caused retarded growth and development and a reduced ratio of phloem/xylem cells in the vascular bundles, suggesting a role in the differentiation of these cells (Holk et al. 2002). Additional studies should be performed to detail the expression profile of this gene in the intercalary meristem during the interaction of sugarcane with $L . x y l i$ subsp. xyli and its possible contribution to the stunting symptom characteristic of RSD.

Hormone metabolism. Plant hormones play key roles in controlling cell division, plant growth and stress responses, and as such it was expected to find genes involved in their metabolism in this study. Genes related to the metabolism of abscisic acid (ABA), ethylene (ET), gibberellin (GA), auxin (IAA), and jasmonic acid (JA) were all up-regulated in L. xyli subsp. xyli-inoculated plants, mostly at 60 DAI. By contrast, no genes related to the synthesis of salicylic acid (SA) were detected. Our results are in general agreement with a previous study on hormonal changes in sugarcane conducted in a similar experimental design (Zhang et al. 2016b). The concentrations of ABA, IAA, and GA were evaluated in plants regenerated from $L$. $x y l i$ subsp. $x y l i$-inoculated setts at 90, 120, 150, and 180 days after shoot emergence. Although the levels of L. xyli subsp. $x y l i$ were not evaluated as in our study, the concentration of ABA increased and of IAA decreased at all evaluation times in inoculated plants compared with noninoculated, whereas the concentration of GA decreased in the inoculated plants only at 180 days. In our study, the up-regulation of the regulatory gene in the biosynthesis of ABA (9-cis-epoxycarotenoid dioxygenase) at 60 DAI was accompanied by the up-regulation of an ABA 8hydroxylase- 1 gene involved in its degradation at the same time, possibly to cope with the increased levels of this hormone in response to higher bacterial titers. The reported reduced levels of IAA could result from the up-regulation of a gene (indole-3-acetic acid-amido synthetase GH3.8) that prevents the accumulation of free IAA (Ding et al. 2008). In addition, it is worth mentioning that the over expression of GH3.8 in rice also hinders plant growth and development (Ding et al. 2008). The up-regulation at 30 DAI of a gene coding for an oxidase (cytochrome P450 ent-kaurenoic acid oxidase) involved in the final three steps of the biosynthetic pathway of GA (Helliwell et al. 2001) suggests an expected increase rather than a decrease in the concentration of this hormone, but this could result from the differences in plant genotypes and times of analysis between our study and that of Zhang et al. (2016b). The up-regulation of three genes involved in the last two steps of the synthesis of ET (one ACC synthase and two ACC oxidases) and of two involved in the metabolism of JA (lipoxygenase [LOX] and a jasmonate ZIM motif protein) extends the range of hormonal responses of sugarcane to $L$. xyli subsp. xyli reported by Zhang et al. (2016b), but additional experiments are needed to confirm their predicted increased levels in planta in response to increased L. xyli subsp. xyli titers.

Our data indicate a more complex hormonal response of sugarcane to L. xyli subsp. xyli than that previously reported by Zhang et al. (2016b). Given the dynamic nature of plant growth control by hormones in response to various stimuli, the development of RSD symptoms is also expected to respond dynamically to varying environmental conditions. As a fact, in plants with stunting the length of the internodes is not uniformly reduced along the stem compared with healthy plants, with some internodes presenting normal length, possibly corresponding to growth periods under more favorable conditions. The balance between ABA production and degradation in response to L. xyli subsp. xyli as suggested in this study could represent an underlying mechanism of this growth pattern, since a combination with any other factor that enhances the production of ABA would aggravate the symptoms. The accentuated severity of RSD reported under conditions of moisture stress (Ngaruiya et al. 2005; Rossler 1974) could be explained by this phenomenon given that the production of $\mathrm{ABA}$ is well recognized to be drought-responsive. The same applies to ET whose synthesis is reciprocally regulated with that of ABA during stress ( $\mathrm{Li}$ and Huang 2011) and inhibits the mitotic cell cycle under high osmotic conditions by reducing the activity of CDKA following a suggested pause-and-stop model (Skirycz et al. 2011) where the cell cycle is rapidly arrested after the sensing of osmotic stress and resumes when conditions improve.

Aside for their role in plant growth, these hormones also play crucial roles in defense, notably ABA, JA, and ET. However, the available information on this pathosystem presently does not allow predicting if the hormonal changes induced by $L$. xyli subsp. xyli act by increasing or decreasing the susceptibility of sugarcane toward this pathogen given that they exert positive or negative roles in disease promotion depending on the characteristics of the interaction. Moreover, it is difficult to determine changes that are directly related to the pathogen attack from those that are side effects of the extensive crosstalk between these hormones.

Signal transduction and transcription regulation associated to plant growth. The alteration of the cell cycle would be expected to be accompanied by changes in signal transduction and regulation of plant growth processes. Most down-regulated genes at 30 DAI involved in signal transduction comprised kinases and two of these were classified as AURORA kinases whose subtypes play different major roles in the cell division cycle, such as regulation of the cycle progression, chromosomal segregation and cytokinesis. In Arabidopsis, the down-regulation of an AURORA kinase by RNAi compromised growth and development by arresting the development of the apical meristem (Petrovská et al. 2012). Two genes coding for Rac GTPase-activating proteins were also downregulated while a WD40-like beta propeller repeat family protein was up-regulated. Besides the cell cycle, these proteins regulate various other cellular processes. On the other hand, at $60 \mathrm{DAI}$, genes encoding for receptor Ser/Thr kinases involved both in plant development and defense were up-regulated in LxxI plants perhaps due to the recognition of the pathogen in the mesophyll and bundle sheath cells after a certain level of cell-density has been achieved. The only LRR receptor serine/threonine-protein kinase downregulated at this time was the ERECTA gene. Arabidopsis mutants of this gene showed short lateral organs and internodes, a phenotype attributed to the arrest of the cell cycle (Van Zanten et al. 2009). Pathogen recognition by receptors could then lead to the differential expression of genes involved in downstream signaling (MAPKKK, calcium dependent protein kinase and calmodulin binding protein) at 60 DAI.

Numerous genes encoding transcription factors (TF) involved in several aspects of plant growth and defense were up or downregulated at both times, reflecting a complex crosstalk between genes with different developmental roles. At 30 DAI, these include down-regulated genes coding for TFs of the SCARECROW-Like 28 (SCL28) class that controls plant development and of the CXCdomain containing residue involved in cell division (Hauser et al. 2000). At 60 DAI, a different and more diverse set of TFs, mostly involved in growth processes and responses to stress with interplay of phytohormones, notably ABA and ET, were detected. These include genes coding for growth regulating factor (GRF), PLATZ, MYB, and NAC TFs. A member of the WRKY51 class that acts as a negative regulator of gibberellin and a positive of ABA signaling (Xie et al. 2006) was up-regulated, agreeing with the reported levels of these hormones in L. xyli subsp. xyli-infected plants (Zhang et al. 2016b). Also noteworthy was the up-regulation of a KNOX $\mathrm{TF}$, once members of this protein family are involved in the maintenance of the meristem. On the other hand, two members of the TCP family of TFs (PCF5 e PCF7) were down-regulated. Members of this family may act by stimulating or inhibiting the cell cycle (Müller and Leyser 2011). Six genes coding for AP2/EREBP family members were down or up-regulated at 30 or $60 \mathrm{DAI}$, two of which were identified as the ethylene-responsive TFs 1 and 4 (ERF1 
and ERF4). The latter is a transcriptional repressor of ET and ABA and was up-regulated at $30 \mathrm{DAI}$ and the former is an ET activator whose up-regulation at $60 \mathrm{DAI}$ coincided with the up-regulation of ACC synthase and ACC oxidase. Finally, at both times chromatin remodeling complex ATPase ISW1 genes involved in cell expansion in Arabidopsis (Huanca-Mamani et al. 2005) were down-regulated.

Host defense through reactive oxygen species (ROS), antimicrobial compounds, and hypoxia. Of the few reported defense responses of sugarcane to $L$. xyli subsp. xyli, the production of ROS seems to be a major one as the activity of the antioxidative stress enzymes superoxide dismutase and peroxidase increased whereas that of catalase decreased in inoculated plants evaluated starting at 150 DAI (Zhang et al. 2016a). Also, increased concentrations of $\mathrm{O}^{2-}$ were reported in L. xyli subsp. xyli-inoculated plants at 240 DAI. Our data support this previous report and indicated that this response can be detected at earlier times at the gene expression level as indicated by the up-regulation of a NADPH respiratory burst oxidase protein $\mathrm{B}$ (Rboh) and of a peroxidase (POX). Three other peroxidase genes were up-regulated at 60 DAI. These genes are responsible for producing ROS which are secreted to the apoplast as defense signaling or accumulated in the vacuole where they contribute to cell wall reinforcement (Almagro et al. 2009) perhaps contributing to the observed uneven thickness of the cell walls observed in L. xyli subsp. xyli-infected plants (Zhang et al. 2016b). Also, increased levels of ROS could make the xylem environment more inhospitable to L. xyli subsp. xyli. The differential expression of a universal stress protein A (USPA) at this time could also be related to ROS production or to a reduction in water availability due to xylem clogging, since its chaperone activity has been related to the control of these oxidative compounds under drought conditions (Isokpehi et al. 2011). In addition to triggering ROS responses, increased bacterial titers at 60 DAI also lead to the up-regulation of genes related to the production of antimicrobial agents, namely phenylalanine ammonia liase (PAL), lipoxygenase (LOX), and cytochrome P450. PAL is the first enzyme in the biosynthesis of phenylpropanoids, from which several antimicrobial compounds are produced (Dixon et al. 2002) whereas LOX, besides participating in the synthesis of JA as mentioned before, generates oxylipins with diverse roles in plant defense against pathogens and insects through the oxidation of fatty acids (Porta and Rocha-Sosa 2002). Cytochrome P450 proteins participate in several cell processes including detoxification of harmful substances and synthesis of defense-related compounds such as phenylpropanoids, alkaloids and terpenoids, as well as the phytohormones GA, auxin and JA (Chapple 1998; Schuler 1996; Schuler and Werck-Reichhart 2003). Metabolomic studies should confirm if these compounds accumulate in sugarcane as a function of L. xyli subsp. xyli colonization and if they exert any inhibitory effect on its growth.

As an obligate aerobe who colonizes the microaerophilic environment of the xylem vessels, it is expected that any changes in the availability of oxygen would have a substantial impact on the ability of $L$. xyli subsp. xyli to grow in the host tissues. The upregulation of genes commonly expressed under hypoxia both at 30 (pyruvate phosphate dikinase [PPDK]; adenylate kinase $[\mathrm{AK}]$ ) and at 60 DAI (pyrophosphate-fructose-6-phosphate 1-phosphotransferase [PFP]; pyruvate decarboxylase [PDC]; alcohol dehydrogenase [ADH]; hypoxia-responsive family protein) in $L$. xyli subsp. $x y l i$-inoculated plants indicates a response of sugarcane to higher bacterial titer toward a reduction in the availability of $\mathrm{O}_{2}$ probably related to hormonal signaling mediated by ET and MYB TFs as suggested by the up-regulation of the ethylene-dependent hypoxiamarker-genes ADH and PDC (Peng et al. 2001).

Pathogen-beneficial transcriptional alterations of the host include suppression of host defenses and up-regulation of genes related to the synthesis of methionine and transport of sugar. Some host physiological modifications induced by pathogens represent remarkable adaptive mechanisms of microorganisms. Viewing L. xyli subsp. xyli as an obligatory endophyte of sugarcane, modification of the host environment would be crucial for its growth and understanding these mechanisms could provide insights as to means of reducing the impact of RSD on sugarcane production. At $30 \mathrm{DAI}$, we observed a down-regulation of genes coding for antimicrobial compounds such as phenylpropanoids (4-coumarate CoA ligase) and the pathogenesis-related proteins (PRproteins) defensin (PR-12) and thaumatin (PR-5) which are markers of systemic acquired resistance. The down-regulation of these genes at 30 DAI may contribute to suppress the plant immune response thus favoring $L$. xyli subsp. xyli growth at the early stages of colonization. By contrast, the up-regulation of a gene coding for methionine synthase (MS) at 30 DAI potentially represent another example of pathogen-beneficial modification since $L$. $x y l i$ subsp. xyli growth in vitro is greatly enhanced by the addition of this amino acid because two genes of the methionine biosynthetic pathway are probably nonfunctional (Monteiro-Vitorello et al. 2004). Thus, an increase in the synthesis of methionine induced by the pathogen at the early phases of colonization, besides up-regulating the synthesis of ET, could also provide the needed supply of this amino acid for pathogen establishment and posterior growth. On the other hand, methionine synthase is also involved in the synthesis and regeneration of S'adenosyl-L-methionine (SAM), which is a precursor of spermidine, a polyamine that is essential for prokaryotic cell growth and protection from various stresses, including ROS (Shah and Swiatlo 2008). As L. xyli subsp. xyli does not have the genes necessary for the synthesis of this compound, it would be interesting to determine the role of spermidine on its growth in the host. Another intriguing finding related to the methionine pathway was the up-regulation of a nicotianamine synthase (NS) gene that is known to be induced under conditions of iron deficiency to produce nicotianamine through the trimerization of SAM. As nicotianamine plays an important role in mineral homeostasis, higher bacterial levels would up-regulate NS to cope with mineral sequestering by the pathogen and a candidate mineral would be iron, since hemin is required for its growth in vitro. SAM is also important to the biosynthesis of ET indicating a major role of methionine in the interaction of sugarcane with L. xyli subsp. xyli.

The up-regulation at 60 DAI of a SWEET14 gene in LxxI plants provides another example of $L$. xyli subsp. xyli-beneficial alteration of sugarcane as it has been proposed that plant pathogens may divert the carbon flux of their hosts to support their own growth by interfering in the expression of genes of the SWEET class of sugar transporters (Chen et al. 2010). Whether this interference results from the action of an effector as in the case of the pthXol effector of the xylem-dwelling Xanthomonas oryzae pv. oryzae which induces the expression of OsSWEET11 (Chen et al. 2010) is an interesting line of research on the pathogenicity mechanisms of $L$. xyli subsp. xyli. Additionally, since SWEET transporters can also enhance pathogen growth through interaction with copper transporters to remove toxic copper from the xylem (Lapin and Van Den Ackerveken 2013), it is interesting to note that a copper export ATPase, which can be involved in $\mathrm{Cu}$ sequestration into the vacuole and/or transport in xylem vessels (Printz et al. 2016) also was upregulated at $60 \mathrm{DAI}$, highlighting the activation of a potential toxic copper removal mechanism by L. xyli subsp. xyli.

Proteomics data. Among the seven differentially accumulated proteins, a calcium-binding chaperone of the endoplasmic reticulum (calreticulin [CRT2]) was less abundant in LxxI plants both at 30 and 60 DAI. Recognized primarily as a regulator of calcium homeostasis in both animals and plants, CRT proteins have also been implicated in a variety of plant processes, such as plant growth and responses to stresses, including pathogen attack. CRT2 is a mediator of salicylic acid-dependent immune responses as the overexpression of the CRT2 gene leads to higher levels of SA and of expression of SAR marker-genes, including PR-5 (Qiu et al. 


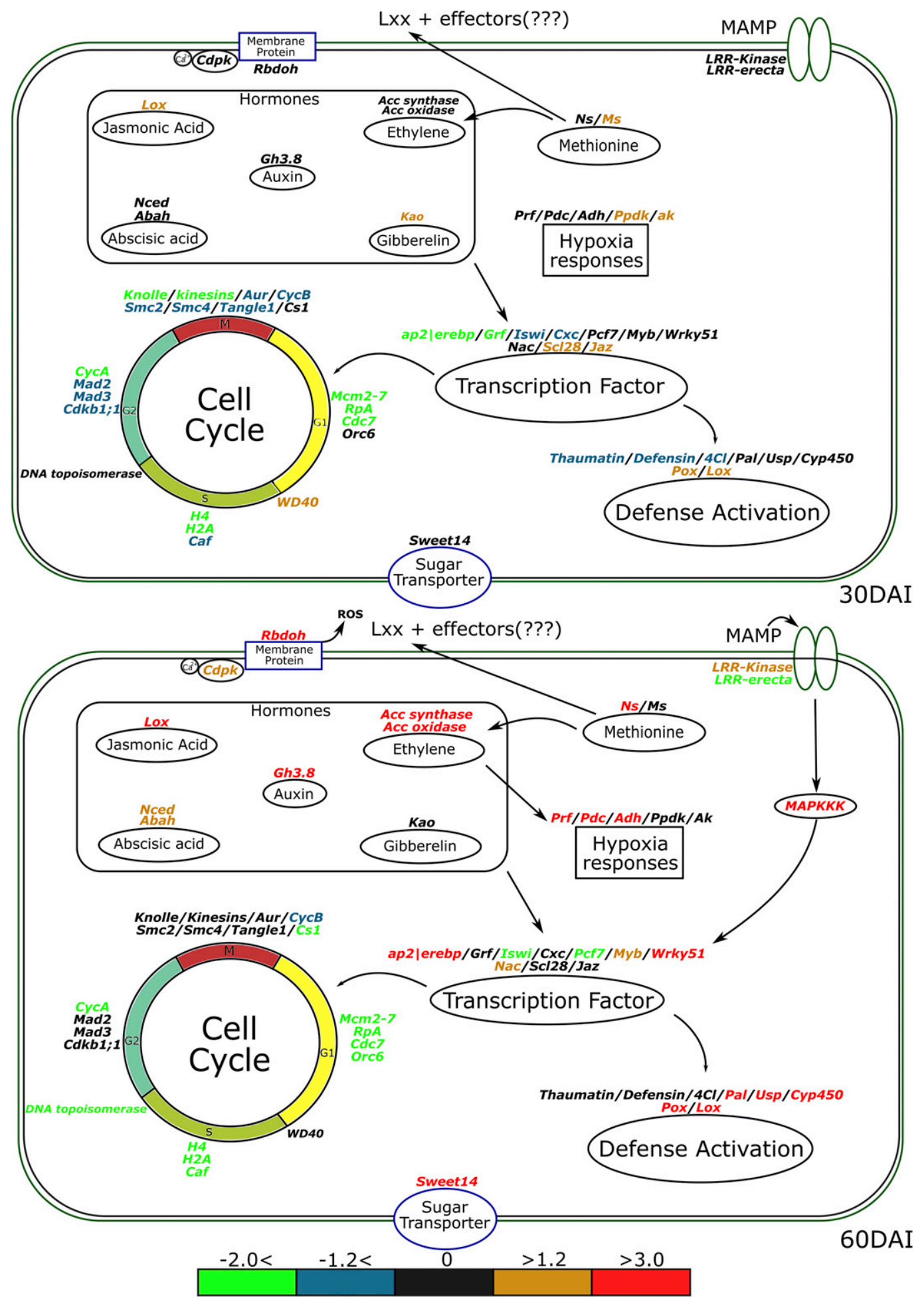

Fig. 5. Schematic representation of the response of sugarcane plant variety SP80-3280 to increased titers of Leifsonia xyli subsp. xyli at A, 30 and B, 60 days after inoculation (DAI). Genes are labeled with colors indicating the fold change $\left(\log _{2}\right)$ of their transcript levels based on microarray data (color code is given in the figure). LRR-erecta, LRR receptor-like serine/threonine-protein kinase ERECTA; LRR-Kinase, LRR receptor-like serine/threonine-protein kinase; MAPKKK, mitogen-activated protein kinase kinase A; Mcm2-7, minichromosome maintenance protein complex 2 to 7; DNA topoisomerase; RpA, replication protein A; Cdc7, Cell division control protein 7; Orc6, origin recognition complex subunit 6; WD40, WD40-like beta propeller repeat family protein; CycA, cyclin A; CycB, cyclin B; H4, histone H4; H2A, histone H2A; Caf, chromatin assembled factor; cdkb1;1, cyclin-dependent protein kinase B1;1; Smc2, structural maintenance of chromosome 2; Smc4, Structural maintenance of chromosome 4; Tangled1, microtubule binding protein Tangled1; Mad2, mitotic spindle checkpoint component MAD2; Mad3, mitotic spindle checkpoint component MAD3; Knolle, syntaxin-related protein KNOLLE; Kinesins; Aur, aurora kinase A; cs1, condensin subunit 1; Ms, methionine synthase; Ns, nicotianamine synthase 3; Pox, peroxidase; Cyp450, cytochrome P450; Adh, alcohol dehydrogenase 1; Ppdk, pyruvate phosphate dikinase; Pdc, pyruvate decarboxylase; Pfp, pyrophosphate-fructose-6-phosphate 1-phosphotransferase; Ak, adenylate kinase; Usp, universal stress protein A; Pal, Phenylalanine ammonia-lyase; 4Cl, 4-Coumarate-CoA ligase; Defensin; Thaumatin; Grf; growth regulation factor; Wrky51, WRKY transcription factor 51; Nac, NAC-domain containing protein; Myb, MYB-like protein; Jaz, jasmonate ZIM motif family protein; Iswi. ISWI chromatin remodeling complex ATPase ISW1; Cxc, Tesmin/TSO1-like CXC domain; ap2/erebp, AP2/ ethylene responsive element binding protein; Scl28, Scarecrow-like protein 28-like; Pcf7, transcription factor PCF7; ACC oxidase; ACC synthase; Nced, 9-cis-epoxycarotenoid dioxygenase; Abah, abscisic acid 8-hydroxylase; LOX, lipoxygenase; GH3.8, Indole-3acetic acid-amido synthetase GH3.8; Kao, cytochrome P450 ent-kaurenoic acid oxidase; Rbdoh, NADPH respiratory burst oxidase homolog protein B; Cdpk, calcium dependent protein kinase; and Sweet14, bidirectional sugar transporter SWEET14. 
2012). Thus, it is reasonable to assume that the observed reduction in the expression of PR-5 observed in LxxI plants at 30 DAI could be related to the lower abundance of CRT2. At 30 DAI, in contrast with the down-regulation of cyclin transcripts of the A and B classes, higher titers of $L$. xyli subsp. xyli lead to increased levels of a $\mathrm{H} ; 1$ class cyclin, whose role in the control of the cell cycle is not firmly established but in Arabidopsis has been associated to drought responses (Zhou et al. 2013). A polyphenol oxidase (PPO) was also more abundant, indicating that the production of quinones with antimicrobial properties may also occur in sugarcane in response to $L$. xyli subsp. xyli along with the production of phenylpropanoids and oxylipins as evidenced from the transcriptomic data. At $60 \mathrm{DAI}$, three spots of glutathione S-transferase, another key enzyme involved in stress response, differentially accumulated in LxxI plants, evidencing a detoxicating reaction of sugarcane to the accumulation of stressing agents perhaps in response to the generation of reactive electrophile species resultant from the up-regulation of cytochrome P450.

Because of the few proteins identified between treatments when LxxI and MI plants were compared within DAI and since there also was a significant increase in L. xyli subsp. xyli titers between mockinoculated plants along the time, we compared the proteomes of the MI and of the LxxI plants between DAI. Since these data are not directly comparable to the results of the microarray analyses because of the variation both in L. xyli subsp. xyli titers and in time, we highlighted some results that tentatively corroborate the transcriptomic data. For instance, changes in protein abundances common to both comparisons (69 out of 148) may represent developmental responses of sugarcane or a common response to the growth of the bacterium since bacterial titers increased over time in both treatments. Also, a larger set of proteins was uniquely identified in the comparison LxxI60 versus LxxI30 where variation in bacterial titer was higher than in the MI60 versus MI30 comparison.

In both comparisons, proteins representing the same major functional categories identified in the microarray analysis were detected and, in some cases, there was a direct gene-protein relationship, such as PAL, methionine synthase, ADH, PFP, and UBC9, whereas in other the results complemented the transcriptomic data. For instance, the accumulation of SAM at higher levels in LxxI plants at 30 DAI compared with 60 DAI together with the up-regulation of the methionine synthase, ACC synthase and ACC oxidase genes completes the pathway from the synthesis of methionine to ET and corroborates the involvement of this hormone in the response to L. $x y l i$ subsp. xyli. Also, evidences of responses to hypoxia, besides being supported by the accumulation of ADH and PFP were strengthened by the accumulation of three protein spots identified as sucrose synthases which are also known to accumulate under this condition. Finally, different components of the ubiquitin/ proteasome system (UPS) were identified at the transcript (ubiquitin conjugating and ligase enzymes [E2 and E3]) and protein levels (five subunits of the proteasome), indicating active protein degradation.

Host growth inhibition and ratoon stunting disease. Despite of its economic importance, there is little information on the effects of RSD on the transcriptome of sugarcane and none so far on its proteome. Once it is still unclear which metabolic pathways are activated as responses of the host to L. xyli subsp. xyli, our study focused on young susceptible plants at the early times of plant and disease development. By inoculating a set of plants, the experimental conditions simulated an increase in the population densities of L. xyli subsp. xyli over time and by comparing their responses to the responses of a set of noninoculated ones, both sets infected with the bacterium, it was possible to detect genes and proteins whose changes in expression or abundances coherently explain the genesis of the main symptom of RSD. An overview of sugarcane responses at the transcriptome level was elaborated (Fig. 5). Our data indicate the negative control of the cell cycle associated with higher bacterial cells as one of the main determinant of stunting. The cumulative negative effects on the division cycle in response to increasing bacterial titers over time modulated by hormones and environmental factors would lead to stunting. Given that the progression of the cell cycle is inhibited by water stress, it is possible that this results from the reported occlusion of the xylem vessels in plants infected with L. xyli subsp. xyli (Teakle et al. 1973). This conclusion is further supported by changes in other genes and proteins associated to drought and hypoxia here reported. However, since LxxI plants did not display visual symptoms of water stress or growth reduction, this conclusion needs to be confirmed by testing for water restriction or xylem clogging under these experimental conditions. Alternatively, it is possible that a yet uncharacterized compound of bacterial origin, perhaps an analog of ABA, might also negatively affect plant growth (Monteiro-Vitorello et al. 2004) and this could be tested, for example, by assessing gene expression after exposing plants to L. xyli subsp. xyli culture filtrates.

L. xyli subsp. xyli behaves similarly to other fastidious and vascular-limited bacteria such as Herbaspirillum rubrisubalbicans and Xanthomonas albilineans in sugarcane, Xylella fastidiosa and Spiroplasma citri in citrus and 'Candidatus phytoplasma mali' in apple, which are detected at low levels in asymptomatic plants and at high levels in symptomatic ones (Alves et al. 2004; Baric et al. 2010; Gutierrez et al. 2016; James et al. 1997; Mello et al. 2010). This dual endophytic/parasitic behavior and its modulation by environmental and host factors is an intriguing aspect of the relationships between plants and microorganisms. For instance, drought is a recognized factor that increases losses due to RSD as it compounds with the occlusion of the xylem in aggravating water stress. Other factors such as the population dynamics of $L$. xyli subsp. xyli over time and in concert with water stress should be explored. Our study described host responses at the gene and protein level and highlighted metabolic pathways that must be studied in more detail to improve our understanding on the genesis of this disease.

\section{LITERATURE CITED}

Almagro, L., Gómez Ros, L. V., Belchi-Navarro, S., Bru, R., Barceló, A. R., and Pedreño, M. A. 2009. Class III peroxidases in plant defence reactions. J. Exp. Bot. 60:377-390.

Alves, E., Marucci, C. R., Lopes, J. R. S., and Leite, B. 2004. Leaf symptoms on plum, coffee and citrus and the relationship with the extent of xylem vessels colonized by Xylella fastidiosa. J. Phytopathol. 152:291-297.

Amalraj, R. S., Selvaraj, N., Veluswamy, G. K., Ramanujan, R. P., Muthurajan, R., Palaniyandi, M., Agrawal, G. K., Rakwal, R., and Viswanathan, R. 2010. Sugarcane proteomics: Establishment of a protein extraction method for 2-DE in stalk tissues and initiation of sugarcane proteome reference map. Electrophoresis 31:1959-1974.

Bailey, R. A. 1977. The systemic distribution and relative occurrence of bacteria in sugarcane varieties affected by ratoon stunting disease. Proc. S. Afr. Sug. Technol. Ass. 6:55-56.

Baric, S., Berger, J., Cainelli, C., Kerschbamer, C., Letschka, T., and Dalla Via, J. 2010. Seasonal colonisation of apple trees by 'Candidatus Phytoplasma mali' revealed by a new quantitative TaqMan real-time PCR approach. Eur. J. Plant Pathol. 129:455-467.

Carvalho, G., da Silva, T. G. E. R., Munhoz, A. T., Monteiro-Vitorello, C. B., Azevedo, R. A., Melotto, M., and Camargo, L. E. A. 2016. Development of a qPCR for Leifsonia xyli subsp. xyli and quantification of the effects of heat treatment of sugarcane cuttings on Lxx. Crop Prot. 80:51-55.

Chapple, C. 1998. Molecular-genetic analysis of plant cytochrome P450dependent monooxygenases. Annu. Rev. Plant Physiol. Plant Mol. Biol. 49: 311-343.

Chen, L.-Q., Hou, B.-H., Lalonde, S., Takanaga, H., Hartung, M. L., Qu, X.-Q., Guo, W.-J., Kim, J.-G., Underwood, W., Chaudhuri, B., Chermak, D., Antony, G., White, F. F., Somerville, S. C., Mudgett, M. B., and Frommeret, W. B. 2010. Sugar transporters for intercellular exchange and nutrition of pathogens. Nature 468:527-534.

Choi, D., Song, J. Y., Kwon, Y. M., and Kim, S. 1996. Characterization of a cDNA encoding a proline-rich $14 \mathrm{kDa}$ protein in developing cortical cells of the roots of bean (Phaseolus vulgaris) seedlings. Plant Mol. Biol. 30: 973-982.

Comstock, J. C., Shine, J. M., Jr., Davis, M. J., and Dean, J. L. 1996. Relationship between resistance to Clavibacter xyli subsp. xyli colonization in 
sugarcane and spread of ratoon stunting disease in the field. Plant Dis. 80: 704-708.

Dal-Bianco, M., Carneiro, M. S., Hotta, C. T., Chapola, R. G., Hoffmann, H. P., Garcia, A. A. F., and Souza, G. M. 2012. Sugarcane improvement: How far can we go? Curr. Opin. Biotechnol. 23:265-270.

Damann, K. E., Jr., and Benda, G. T. A. 1983. Evaluation of commercial heat treatment methods for control of ratoon stunting disease of sugarcane. Plant Dis. 67:966-967.

Davis, M. J., Dean, J. L., and Harrison, N. A. 1988. Quantitative variability of Clavibacter xyli subsp.. xyli populations in sugarcane cultivars differing in resistance to ratoon stunting disease. Phytopathology 78:462-468.

Dean, J. L., and Davis, M. J. 1990. Losses caused by ratoon stunting disease of sugarcane in Florida. Am. Soc. Sugar Cane Technol. 10:66-72.

Ding, X., Cao, Y., Huang, L., Zhao, J., Xu, C., Li, X., and Wang, S. 2008. Activation of the indole-3-acetic acid-amido synthetase GH3-8 suppresses expansin expression and promotes salicylate- and jasmonate-independent basal immunity in rice. Plant Cell 20:228-240.

Dixon, R. A., Achnine, L., Kota, P., Liu, C.-J., Reddy, M. S. S., and Wang, L. 2002. The phenylpropanoid pathway and plant defense-A genomics perspective. Mol. Plant Pathol. 3:371-390.

Fegan, M., Croft, B. J., Teakle, D. S., Hayward, C., and Smith, G. R. 1998. Sensitive and specific detection of Clavibacter xyli subsp. xyli, causal agent of ratoon stunting disease of sugarcane, with a polymerase chain reactionbased assay. Plant Pathol. 47:495-504.

Ferro, M., de Barros, N., Dabbas, K., Laia, M., Kupper, K., Moraes, V., Oliveira, J. C. F., Ferro, J. A., and Zingaretti, S. M. 2007. Análise do perfil de expressão dos genes da cana-de-açúcar envolvidos na interação com Leifsonia xyli subsp. xyli. Summa Phytopathol. 33:157-166.

Gutierrez, A., Garces, F. F., and Hoy, J. W. 2016. Evaluation of resistance to leaf scald by quantitative PCR of Xanthomonas albilineans in sugarcane. Plant Dis. 100:1331-1338.

Hauser, B. A., He, J. Q., Park, S. O., and Gasser, C. S. 2000. TSO1 is a novel protein that modulates cytokinesis and cell expansion in Arabidopsis. Development 127:2219-2226.

Helliwell, C. A., Chandler, P. M., Poole, A., Dennis, E. S., and Peacock, W. J. 2001. The CYP88A cytochrome P450, ent-kaurenoic acid oxidase, catalyzes three steps of the gibberellin biosynthesis pathway. Proc. Natl. Acad. Sci. USA 98:2065-2070.

Holk, A., Klumpp, L., and Scherer, G. F. E. 2002. A cell wall protein downregulated by auxin suppresses cell expansion in Daucus carota (L. ). Plant Mol. Biol. 50:295-305.

Huanca-Mamani, W., Garcia-Aguilar, M., León-Martínez, G., Grossniklaus, U., and Vielle-Calzada, J.-P. 2005. CHR11, a chromatin-remodeling factor essential for nuclear proliferation during female gametogenesis in Arabidopsis thaliana. Proc. Natl. Acad. Sci. USA 102:17231-17236.

Inzé, D., and De Veylder, L. 2006. Cell cycle regulation in plant development. Annu. Rev. Genet. 40:77-105.

Isokpehi, R. D., Simmons, S. S., Cohly, H. H. P., Ekunwe, S. I. N., Begonia, G. B., and Ayensu, W. K. 2011. Identification of drought-responsive universal stress proteins in Viridiplantae. Bioinform. Biol. Insights 5:BBIS6061.

James, E. K., Olivares, F. L., Baldani, J. I., and Döbereiner, J. 1997. Herbaspirillum, an endophytic diazotroph colonizing vascular tissue Sorghum bicolor L. Moench. J. Exp. Bot. 48:785-798.

John, I., Wang, H., Held, B., Wurtele, E., and Colbert, J. 1992. An mRNA that specific accumulates in maize roots delineate a novel subset of developing cortical cells. Plant Mol. Biol. 20:821-831.

Kao, J., and Damann, K. E., Jr. 1978. Microcolonies of the bacterium associated with ratoon stunting disease found in sugarcane xylem matrix. Phytopathology 68:545-551.

Lapin, D., and Van Den Ackerveken, G. 2013. Susceptibility to plant disease: more than a failure of host immunity. Trends Plant Sci. 18:546-554.

Lauber, M. H., Waizenegger, I., Steinmann, T., Schwarz, H., Mayer, U., Hwang, I., Lukowitz, W., and Jürgens, G. 1997. KNOLLE protein is a cytokinesis-specific syntaxin. J. Cell Biol. 139:1485-1493.

Lembke, C. G., Nishiyama, M. Y., Sato, P. M., de Andrade, R. F., and Souza, G. M. 2012. Identification of sense and antisense transcripts regulated by drought in sugarcane. Plant Mol. Biol. 79:461-477.

Li, J., Xu, Y., and Chong, K. 2012. The novel functions of kinesin motor proteins in plants. Protoplasma 249(suppl.):95-100.

Li, W.-F., Shen, K., Huang, Y.-K., Wang, X.-Y., Yin, J., Luo, Z.-M., Zhang, R.-Y., and Shan, H.-L. 2014. Incidence of sugarcane ratoon stunting disease in the major cane-growing regions of China. Crop Prot. 60:44-47.

Li, Z., and Huang, R. 2011. The reciprocal regulation of abscisic acid and ethylene biosyntheses. Plant Signal. Behav. 6:1647-1650.

Madan, V., Singh, K., Shukla, U., and Sayena, Y. 1986. Biochemical studies on sugarcane (Saccharum officinarum L.) affected with ratoon stunting disease. Indian Phytopathol. 39:506-508.

Maier, T., Güell, M., and Serrano, L. 2009. Correlation of mRNA and protein in complex biological samples. FEBS Lett. 583:3966-3973.
McFarlane, S. 2002. The relationship between extent of colonisation by Leifsonia xyli subsp. xyli and yield loss in different sugarcane varieties. Proc. S. Afr. Sug. Technol. Ass. 76:281-284.

Mello, A., Yokomi, R., Melcher, U., Chen, J., and Fletcher, J. 2010. Citrus stubborn severity is associated with Spiroplasma citri titer but not with bacterial genotype. Plant Dis. 94:75-82.

Mills, L., Leaman, T. M., Taghavi, S. M., Shackel, L., Dominiak, B. C., Taylor, P. W. J., Fegan, M., and Teakle, D. S. 2001. Leifsonia xyli-like bacteria are endophytes of grasses in eastern Australia. Australas. Plant Pathol. 30: $145-151$

Monteiro-Vitorello, C. B., Camargo, L. E. A., Van Sluys, M. A., Kitajima, J. P., Truffi, D., do Amaral, A. M., Harakava, R., de Oliveira, J. C., Wood, D., de Oliveira, M. C., Miyaki, C., Takita, M. A., da Silva, A. C., Furlan, L. R., Carraro, D. M., Camarotte, G., Almeida, N. F., Jr., Carrer, H., Coutinho, L. L., El-Dorry, H. A., Ferro, M. I., Gagliardi, P. R., Giglioti, E., Goldman, M. H., Goldman, G. H., Kimura, E. T., Ferro, E. S., Kuramae, E. E., Lemos, E. G., Lemos, M. V., Mauro, S. M., Machado, M. A., Marino, C. L., Menck, C. F., Nunes, L. R., Oliveira, R. C., Pereira, G. G., Siqueira, W., de Souza, A. A., Tsai, S. M., Zanca, A. S., Simpson, A. J., Brumbley, S. M., and Setúbal, J. C. 2004. The genome sequence of the gram-positive sugarcane pathogen Leifsonia xyli subsp. xyli. Mol. Plant-Microbe Interact. 17:827-836.

Müller, D., and Leyser, O. 2011. Auxin, cytokinin and the control of shoot branching. Ann. Bot. 107:1203-1212.

Ngaruiya, P. N., Shipton, W. A., and Coventry, R. 2005. Ratoon stunting disease of sugarcane as influenced by environmental stressors. Proc. Aust. Soc. Sugar Cane Technol. 27:324-333.

Papini-Terzi, F., Rocha, F., Vêncio, R., Oliveira, K., Felix, J., Vicentini, R., Rocha, C. S., Simões, A. C., Ulian, E. C., di Mauro, S. M., da Silva, A. M., Pereira, C. A., Menossi, M., and Souza, G. M. 2005. Transcription profiling of signal transduction-related genes in sugarcane tissue. DNA Res. 12: 27-38.

Peng, H.-P., Chan, C.-S., Shih, M.-C., and Yang, S. F. 2001. Signaling events in the hypoxic induction of alcohol dehydrogenase gene in Arabidopsis. Plant Physiol. 126:742-749.

Petrovská, B., Cenklová, V., Pochylová, Ž., Kourová, H., Doskočilová, A., Plíhal, O., Binarová, L., and Binarová, P. 2012. Plant Aurora kinases play a role in maintenance of primary meristems and control of endoreduplication. New Phytol. 193:590-604.

Pfaffl, M. W., Horgan, G. W., and Dempfle, L. 2002. Relative expression software tool (REST) for group-wise comparison and statistical analysis of relative expression results in real-time PCR. Nucleic Acids Res. 30:e36.

Ponte, E. C., Silveira, S. F., Carneiro, J. D. B., Jr., and Lima, R. M. P. 2010. Incidência de Leifsonia xyli subsp. xyli em áreas de multiplicação de canade-açúcar no Espírito Santo, sul da Bahia e oeste de Minas Gerais. Summa Phytopathol. 36:313-321.

Porta, H., and Rocha-Sosa, M. 2002. Plant lipoxygenases. Physiological and molecular features. Plant Physiol. 130:15-21.

Printz, B., Lutts, S., Hausman, J.-F., and Sergeant, K. 2016. Copper trafficking in plants and its implication on cell wall dynamics. Front. Plant Sci. 7:601.

Qiu, Y., Xi, J., Du, L., Roje, S., and Poovaiah, B. W. 2012. A dual regulatory role of Arabidopsis calreticulin-2 in plant innate immunity. Plant J. 69: 489-500.

Quecine, M. C., Silva, T. M., Carvalho, G., Saito, S., Mondin, M., Teixeira-Silva, N. S., Camargo, L. E. A., and Monteiro-Vitorello, C. B. 2015. A stable Leifsonia xyli subsp. xyli GFP-tagged strain reveals a new colonization niche in sugarcane tissues. Plant Pathol. 65:154-162.

Rago, B. A. M., Acreche, M. M., Sopena, R. A., and Mariotti, J. A. 2004. A survey of ratoon stunting disease (Leifsonia xyli subsp. xyli) in commercial sugarcane fields at Tucumán. Sugar Cane Int. 22:12-14.

Ramakers, C., Ruijter, J. M., Deprez, R. H. L., and Moorman, A. F. 2003. Assumption-free analysis of quantitative real-time polymerase chain reaction (PCR) data. Neurosci. Lett. 339:62-66.

Rossler, L. 1974. The effects of ratoon stunting disease on three sugarcane varieties under different irrigation regimes. Proc. Int. Soc. Sugarcane Technol. 1:250-257.

Schuler, M. A. 1996. The role of cytochrome P450 monooxygenases in plant-insect interactions. Plant Physiol. 112:1411-1419.

Schuler, M. A., and Werck-Reichhart, D. 2003. Functional genomics of P450. Annu. Rev. Plant Biol. 54:629-667.

Shah, P., and Swiatlo, E. 2008. A multifaceted role for polyamines in bacterial pathogens. Mol. Microbiol. 68:4-16.

Skirycz, A., Claeys, H., De Bodt, S., Oikawa, A., Shinoda, S., Andriankaja, M., Maleux, K., Eloy, N. B., Coppens, F., Yoo, S.-D., Saito, K., and Inzé, D. 2011. Pause-and-stop: The effects of osmotic stress on cell proliferation during early leaf development in Arabidopsis and a role for ethylene signaling in cell cycle arrest. Plant Cell 23:1876-1888.

Smith, L. G., Gerttula, S. M., Han, S., and Levy, J. 2001. TANGLED1: A microtubule binding protein required for the spatial control of cytokinesis in maize. J. Cell Biol. 152:231-236. 
Teakle, D., Smith, P., and Steindl, D. 1973. Association of a small coryneform bacterium with the ratoon stunting disease of sugar-cane. Aust. J. Agric. Res. 24:869-874.

Teakle, D. S., Appleton, J. M., and Steindl, D. R. L. 1978. An anatomical basis for resistance of sugar cane to ratoon stunting disease. Physiol. Plant Pathol. 12:83-91.

Teakle D. S., and Ryan, C. C. 1992. The effect of high temperature on the sugarcane ratoon stunting disease bacterium, Clavibacter xyli subsp. xyli, in vitro and in vivo. SugarCane 6:5-6.

Untergasser, A., Nijveen, H., Rao, X., Bisseling, T., Geurts, R., and Leunissen, J. A. M. 2007. Primer3Plus, an enhanced web interface to Primer3. Nucleic Acids Res. 35:W71-W74.

Urashima, A. S., and Marchetti, L. B. L. 2013. Incidence and severity of Leifsonia xyli subsp. xyli infection of sugarcane in São Paulo State, Brazil. J. Phytopathol. 161:478-484.

Urashima, A. S., Silva, M. F., Correa, J. J., Moraes, M. C., Singh, A. V., Smith, E. C., and Sainz, M. B. 2017. Prevalence and severity of ratoon stunt in commercial Brazilian sugarcane fields. Plant Dis. 101:815-821.

Van Zanten, M., Snoek, L. B., Proveniers, M. C. G., and Peeters, A. J. M. 2009. The many functions of ERECTA. Trends Plant Sci. 14:214-218.

Vêncio, R. Z. N., and Koide, T. 2005. HTself: Self-self based statistical test for low replication microarray studies. DNA Res. 12:211-214.

Vettore, A. L., Silva, F. R., Kemper, E. L., Souza, G. M., Silva, A. M., Ferro, M. I., Henrique-Silva, F., Giglioti, E. A., Lemos, M. V., Coutinho, L. L., Nobrega, M. P., Carrer, H., França, S. C., Bacci, M., Jr., Goldman, M. H., Gomes, S. L., Nunes, L. R., Camargo, L. E. A., Siqueira, W. J., Van Sluys, M. A., Thiemann, O. H., Kuramae, E. E., Santelli, R. V., Marino, C. L., Targon, M. L., Ferro, J. A., Silveira, H. C., Marini, D. C., Lemos, E. G., Monteiro-Vitorello, C. B., Tambor, J. H., Carraro, D. M., Roberto, P. G., Martins, V. G., Goldman, G. H., de Oliveira, R. C., Truffi, D., Colombo, C. A., Rossi, M., de Araujo, P. G., Sculaccio, S. A., Angella, A., Lima, M. M., de Rosa, V. E., Jr., Siviero, F., Coscrato, V. E., Machado, M. A., Grivet, L., Di Mauro, S. M., Nobrega, F. G., Menck, C. F., Braga, M. D., Telles, G. P., Cara, F. A., Pedrosa, G., Meidanis, J., and Arruda, P. 2003.
Analysis and functional annotation of an expressed sequence tag collection for tropical crop sugarcane analysis and functional annotation of an expressed sequence tag collection for tropical crop sugarcane. Genome Res. 13:2725-2735.

Xie, Z., Zhang, Z. L., Zou, X., Yang, G., Komatsu, S., and Shen, Q. J. 2006. Interactions of two abscisic-acid induced WRKY genes in repressing gibberellin signaling in aleurone cells. Plant J. 46:231-242.

Young, A., Petrasovits, L., Croft, B., Gillings, M., and Brumbley, S. M. 2006. Genetic uniformity of international isolates of Leifsonia xyli subsp. xyli, causal agent of ratoon stunting disease of sugarcane. Australas. Plant Pathol. 35:503-511.

Young, A. J. 2016. Possible origin of ratoon stunting disease following interspecific hybridization of Saccharum species. Plant Pathol. 65:1403-1410.

Zavaglia, A. C., Cia, M. C., Popin, R. V., and Camargo, L. E. A. 2016. No alternative hosts of the sugarcane pathogen Leifsonia xyli subsp. xyli were identified among grass and non-grass species using novel PCR primers. Trop. Plant Pathol. 41:336-339.

Zekarias, Y., Yirefu, F., Baissa, T., Tafesse, A., and Mengistu, L. 2012. Effect of Leifsonia xyli subsp. xyli concentration on yields of four sugarcane varieties in the sugarcane plantations of Ethiopia. Ethiop. J. Sci. Technol. 3: 25-30.

Zhang, X., Chen, M., Liang, Y., Xing, Y., Comstock, J. C., Li, Y., and Yang, L. 2016b. Morphological and physiological responses of sugarcane to Leifsonia xyli subsp. xyli infection. Plant Dis. 100:2499-2506.

Zhang, X., Liang, Y., Zhu, K., Wu, C.-X., Yang, L., and Li, Y. 2016 a. Influence of inoculation of Leifsonia xyli subsp. xyli on photosynthetic parameters and activities of defense enzymes in sugarcane. Sugar Tech 19:394-401.

Zhou, X. F., Jin, Y. H., Yoo, C. Y., Lin, X. L., Kim, W. Y., Yun, D. J., Bressan, R. A., Hasegawa, P. M., and Jin, J. B. 2013. CYCLIN H;1 regulates drought stress responses and blue light-induced stomatal opening by inhibiting reactive oxygen species accumulation in Arabidopsis. Plant Physiol. 162: 1030-1041. 